\title{
Assessment of heavy metal and bacterial pollution in coastal aquifers from SIPCOT industrial zones, Gulf of Mannar, South Coast of Tamil Nadu, India
}

\author{
S. Selvam ${ }^{1}$ A. Antony Ravindran ${ }^{1} \cdot$ S. Venkatramanan ${ }^{2} \cdot$ C. Singaraja ${ }^{3}$
}

Received: 26 March 2014/ Accepted: 15 June 2015/Published online: 27 June 2015

(c) The Author(s) 2015. This article is published with open access at Springerlink.com

\begin{abstract}
Heavy metals and microbiological contamination were investigated in groundwater in the industrial and coastal city of Thoothukudi. The main sources of drinking water in this area are water bores which are dug up to the depth of $10-50 \mathrm{~m}$ in almost every house. A number of chemical and pharmaceutical industries have been established since past three decades. Effluents from these industries are reportedly being directly discharged onto surrounding land, irrigation fields and surface water bodies forming point and non-point sources of contamination for groundwater in the study area. The study consists of the determination of physico-chemical properties, trace metals, heavy metals and microbiological quality of drinking water. Heavy metals were analysed using Inductively Coupled Plasma Mass Spectrometry and compared with the (WHO in Guidelines for drinking water quality, 2004) standards. The organic contamination was detected in terms of most probable number (MPN) test in order to find out faecal coliforms that were identified through biochemical tests. A comparison of the results of groundwater samples with WHO guidelines reveals that most of the groundwater samples are heavily contaminated with heavy metals like arsenic, selenium, lead, boron, aluminium, iron and vanadium. The selenium level was higher than
\end{abstract}

S. Selvam

geoselvam10@gmail.com

1 Department of Geology, V. O. Chidambaram College, Thoothukudi 628008, Tamil Nadu, India

2 Department of Earth \& Environmental Sciences, Institute of Environmental Geosciences, Pukyong National University, Busan 608-737, Korea

3 Department of Geology, Presidency College, Chennai 600005, India
$0.01 \mathrm{mg} / \mathrm{l}$ in $82 \%$ of the study area and the arsenic concentration exceeded $0.01 \mathrm{mg} / \mathrm{l}$ in $42 \%$ of the area. The results reveal that heavy metal contamination in the area is mainly due to the discharge of effluents from copper industries, alkali chemical industry, fertiliser industry, thermal power plant and sea food industries. The results showed that there are pollutions for the groundwater, and the total Coliform means values ranged from 0.6-145 $\mathrm{MPN} \mathrm{ml}^{-1}$, faecal Coliform ranged from 2.2-143 $\mathrm{MPN} \mathrm{ml}^{-1}$, Escherichia coli ranged from 0.9 to $40 \mathrm{MPN} \mathrm{ml} \mathrm{m}^{-1}$ and faecal streptococci ranged from $10-9.20 \times 10^{2} \mathrm{CFU} \mathrm{ml}^{-1}$. The coastal regions are highly contaminated with total coliform bacteria, faecal coliform bacteria and E. coli. This might be due to the mixing of sewage from Thoothukudi town through the Buckle channel and fishing activity.

Keywords Groundwater - ICP-MS · Heavy metals · MPN · WHO - Thoothukudi

\section{Introduction}

Groundwater is one of the most vital resources for the sustenance of humans, plants and other living beings. It is required in all aspects of life for producing food for agricultural activities and for energy generation. Groundwater is rarely treated presuming being a naturally protected source. It is considered to be free from impurities, which are associated with surface water, because it comes from deeper parts of the earth. Increasing population and rapid urbanization has lead to several environmental problems including groundwater pollution.

The accumulation of Trace metals in groundwater has direct consequences to both man and the ecosystem. There 
are two main sources of heavy metals in groundwater (i) natural (ii) anthropogenic sources. The natural sources include the release of metals from rock weathering and their final leaching into groundwater by rock water interaction. The anthropogenic sources include discharge of heavy metals into the atmosphere by burning of fossil fuels/industrial activities and, thereby, to the streams by rain and also through discharge of industrial effluents and sewage water into streams and surface water bodies (Antony Ravindran and Selvam 2014; Dutka and Bell 1973; Handa 1981; Leung and Jiao 2006; Selvam and Sivasubramanian 2012a; Singaraja et al. 2015).

Drinking water is a major source of microbial pathogens in developing regions, although poor sanitation and food sources are integral to enteric pathogen exposure (Macler and Merkel 2000; Lerner and Harris 2009). The lack of safe drinking water and adequate sanitation measures lead to a number of diseases such as cholera, dysentery, salmonellosis and typhoid, and every year millions of lives are claimed in developing countries (Van Ryneveld and Fourie 1997). Groundwater is the main source of drinking water in the villages without any treatment. It may be contaminated by disease-producing pathogens, leachate from landfills and septic systems, careless disposal of hazardous household products, agricultural chemicals and leaking underground storage tanks.

Interest in metals like zinc $(\mathrm{Zn})$ and copper $(\mathrm{Cu})$, which are required for metabolic activity in organisms, lies in the narrow "window" between their essentiality and toxicity. Others like aluminium $(\mathrm{Al})$, cadmium $(\mathrm{Cd})$ and lead $(\mathrm{Pb})$ exhibit extreme toxicity even at trace levels (Vanloon and Duffy 2005; Puthiyasekar et al. 2010). The quality of water has now become an important topic in all the countries, especially with respect to drinking water. Although water plays an essential role in human life, it has a great potential for transmitting a wide variety of diseases and illnesses. Contaminated water-related conditions result in cholera, dysentery, typhoid fever, ring worms, skin irritation and any other illnesses associated with the consumption and use of poor water supplies.

Heavy metals are major toxic pollutants that severely limit the beneficial use of water for domestic or industrial applications (Nouri et al. 2006). Groundwater pollution over the years, due to contaminant leaking from the disposal sites, is a big problem in many countries. Industries such as ceramic, painting, glass, mining and battery manufacturing are considered the main sources of heavy metals in local water streams and it eventually contaminates the groundwater with heavy metals. Land fill leachate site is another source of heavy metal contamination in groundwater (Sang et al. 2008). Increase in human activities such as industrialization coupled with over population and increase in ambient temperature are amongst the other factors that have become major environmental issues in recent years. Exposure to very low levels of elements such as lead, cadmium and mercury have been shown to have a cumulative effects on humans since there is no homeostatic mechanism that can operate to regulate the levels of these toxic substances (Carter and Fernando 1979). This study reports the levels of dissolved trace elements and heavy metals in the ground water system. The coastal area supports a rapidly growing population and there are concerns regarding the water quality of the ground water system. The main uses of water in the catchment area are domestic and agricultural (livestock watering) (Carter and Fernando 1979). Therefore, the presence of high concentration levels of heavy metals in the environment presents a potential danger to human health due to their extreme toxicity (Fatoki et al. 2012). The objective of this study was to assess the heavy metal and microbiological concentration in the groundwater samples of Thoothukudi Corporation, South Coast of Tamil Nadu, Gulf of Mannar and its relation to the highly developed industrial activities. The area is highly industrialized, and it is the main source of pollution. The waste products released from the anthropogenic activities like poultry farms, chemical, pharmaceuticals, and other industries constitute the main cause for the degradation of water quality in the area. Considering this factor and keeping an account of the importance of public health, this study was designed to understand the present status of trace elements and microbiological quality in groundwater of coastal city of Thoothukudi, Tamil Nadu, India. The results obtained will establish a baseline data for future reference.

\section{Study area}

Thoothukudi coastal area extends over approximately $206.3 \mathrm{sq} \mathrm{km}$ and lies between $8^{\circ} 43^{\prime}-8^{\circ} 51^{\prime} \mathrm{N}$ latitude and $78^{\circ} 5^{\prime}-78^{\circ} 10^{\prime} \mathrm{E}$ longitude in the southern part of Tamil Nadu, India (Fig. 1). Thoothukudi city and surrounding areas have considerable presence of industries in several industrial sectors. The large industries (other than infrastructure providers, i.e. the Port and the Tamil Nadu Electricity Board Power Plant) are Sterlite (copper), Southern Petrochemical Industrial Corporation (fertilisers and chemicals) and Kilburn Chemicals (titanium dioxide). There are also several textile mills in the district. The presence of these large industries can lead to the establishment of industries that have product synergies with these units (Selvam et al. 2013a, b). Several medium and small industries, including traditional ones, are situated in Thoothukudi and its neighbourhood. The major segments include salt-industrial and domestic, marine products, minerals (Ilmenite, Garnet, etc.), dry flower exports, edible oil extraction, readymade garments and senna (medicinal 


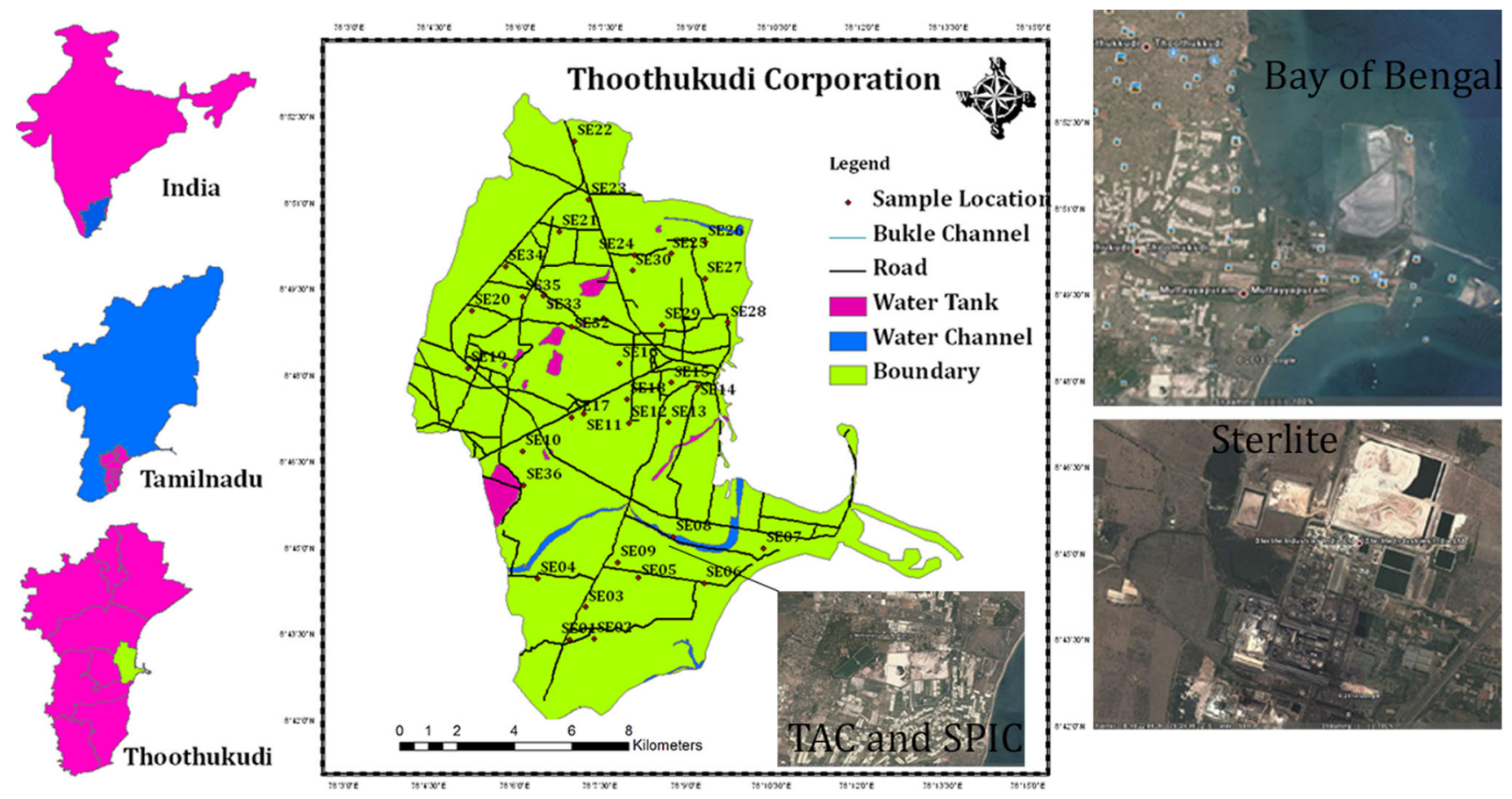

Fig. 1 Location of the study area and the sampling sites with industrial sectors

herbs) exports (Selvam 2014e, 2015). This study reports the levels of dissolved trace elements and heavy metals in the groundwater system. The coastal study area supports a rapidly growing population and there are concerns regarding the water quality of the groundwater system. A large number of researchers have also worked on trace element contents of groundwater in Indian subcontinent and along its coastal area (Ramesh et al. 1995; Mandal and Sengupta 2006).

\section{Geological setting}

About $90 \%$ of the study area is made up of sedimentary rocks of Tertiary to Recent age comprising Shell limestone and Sand, Tuffaceous Kankar, Sand (Aeolian deposits), etc., and the remaining area is covered by mixed and composite gneiss of Proterozoic age of crystalline rocks (Fig. 2). The sedimentary rocks are fine to medium grained, hard, compact and fossiliferous with shells of gastropods and pelecypods. The thickness of the strata varies from place to place, from a few metres to more than $20 \mathrm{~m}$. The formation extends in the NE-SW direction dipping SE with low angles. Sand admixed with clay is the major formation making the aquifer media. The coastal study area is underlined by loose textured coarse calcareous grits and shell limestone of sub-recent age. Rocks are horizontally bedded with a low dip of $10^{\circ}-15^{\circ} \mathrm{SE}$. The Archaean groups of formations are crystalline and metamorphic, and finely foliated with a general NW-SE trend described by (Balasubramanaian et al. 1993). The area is covered with black soils in the western part (Sankarapari area), red soil (sandy loam to sandy soil) in the central part and alluvial sandy soils (Coastal area) in the eastern part. The maximum soil thickness is about $3 \mathrm{~m}$. The sandy soils originated from sandstones have low soil moisture receptivity. The alluvium soils are wind-blown sands and shells that constitute beach sand and coastal dunes, and have very low soil moisture retentivity. The important aquifer systems in the district are constituted by unconsolidated and semi-consolidated formations and weathered and fractured crystalline rocks. The porous formations in the district include sandstones of Tertiary age. The recent formations comprising mainly sands, clays and gravels are confined to major drainage courses in the district. The maximum thickness of alluvium is $45.0 \mathrm{~m} \mathrm{bgl}$, whereas the average thickness is about $25.0 \mathrm{~m}$ (Selvam 2012b).

\section{Materials and methods}

A total of 36 groundwater samples were collected from open wells and bore holes ranging in depth between 6 and $86 \mathrm{~m}$ BGL for summer season 2012 (Table 1). Sample was collected by acid-washed polyethylene 1000-ml HDPE bottle. The bottle was completely filled with water taking care that no air bubble was trapped within the water sample. Then to prevent evaporation, the double plastic caps of the bottles were sealed. Precaution was also taken to avoid 
Fig. 2 Geology map of the Thoothukudi Corporation

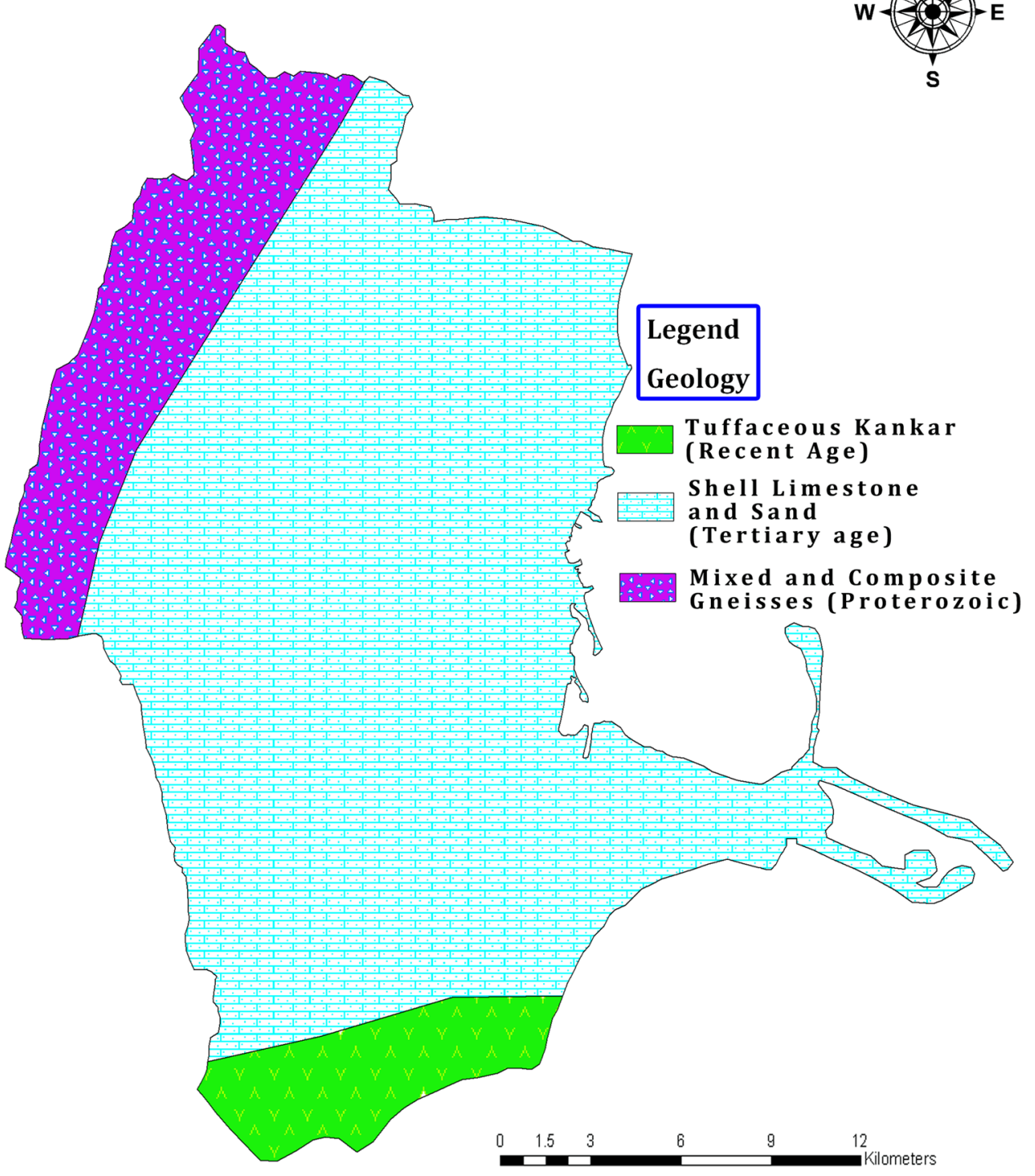

sample agitation during transfer to the laboratory. The samples were stored at a temperature below $4{ }^{\circ} \mathrm{C}$ prior to analysis in the laboratory. $\mathrm{pH}, \mathrm{EC}$ and TDS were measured using portable water quality analysers. Major cations $(\mathrm{Ca}$, $\mathrm{Mg}, \mathrm{Na}$ and $\mathrm{K}$ ) were determined using ICP-Mass Spectrometer, while the anions were determined as follows: bicarbonate $\left(\mathrm{HCO}_{3}\right)$ and Total hardness $(\mathrm{TH})$ were analysed by volumetric method, sulphate $\left(\mathrm{SO}_{4}\right)$ was estimated by the spectrophotometric technique and nitrate $\left(\mathrm{NO}_{3}\right)$ was determined by ion chromatography. Chloride $(\mathrm{Cl})$ was determined by volumetric titration using $\mathrm{AgNO}_{3}$ and $\mathrm{K}_{2} \mathrm{Cr}$, $\mathrm{HCO}_{3}$ and carbonate $\left(\mathrm{CO}_{3}\right)$ was determined by Portamess using $\mathrm{HCl}$, phenolphthalein, methyl orange by titration method. Fluoride was estimated by using an ion-selective electrode (ISE) with a $\mathrm{pH} / \mathrm{ISE}$ meter (Orion 4-Star meter). All concentrations are expressed in milligrams per litre (mg/l), except $\mathrm{pH}$ and EC. The heavy metals water samples were collected in pre-cleaned (with $1 \mathrm{~N} \mathrm{HCl}$ ) polyethylene 500-ml HDPE bottles which are filtered, acidified with nitric acid (1 N) and analysed for heavy metals at geochemistry laboratory of National Geophysical Research Institute, Hyderabad by using Inductively Coupled Plasma Mass Spectrometer (ICP-MS) Model ELAN DRC II, Perkin-Elmer Sciex Instrument, USA. The results were evaluated in accordance with the drinking water quality standards given by the World Health Organization (WHO 2004).

\section{Microbiological analysis}

Microbiological quality of water was determined using most probable number (MPN) methods (International 
Table 1 Groundwater well inventory and characteristics in the study area

\begin{tabular}{|c|c|c|c|c|c|c|c|c|}
\hline Sample ID & Location Name & Latitude & Longitude & Total depth (m) & Depth to water table (m) & $\mathrm{pH}$ & $\mathrm{EC}(\mu \mathrm{s} / \mathrm{cm})$ & TDS \\
\hline SE 01 & Mullakadu & 78.1158 & 8.7241 & 12 & 7 & 7.8 & 2430 & 1450 \\
\hline SE 02 & Muniasamy Puram & 78.123 & 8.7243 & 13.6 & 11.4 & 7.8 & 2640 & 1570 \\
\hline SE 03 & Geetha nagar & 78.1204 & 8.7335 & 13 & 8.7 & 7.4 & 3900 & 2400 \\
\hline SE 04 & Athimarapati & 78.1064 & 8.7418 & 10.3 & 7.1 & 7.8 & 1080 & 710 \\
\hline SE 05 & Susai nagar & 78.1356 & 8.7421 & 19.3 & 15.4 & 7.4 & 4180 & 2700 \\
\hline SE 06 & Tsunami nagar & 78.1548 & 8.7407 & 13.6 & 9.5 & 7.7 & 1520 & 980 \\
\hline SE 07 & Harbour quateres & 78.1721 & 8.7509 & 9.2 & 5.5 & 7.7 & 1280 & 790 \\
\hline SE 08 & Camp I quateres & 78.1459 & 8.7541 & 19.6 & 13.1 & 7.6 & 10,000 & 6000 \\
\hline SE 09 & Muthiapuram & 78.1297 & 8.7466 & 19 & 16 & 7.4 & 2720 & 1620 \\
\hline SE 10 & Periyanayaga Puram & 78.1016 & 8.7785 & 19.6 & 11.3 & 7.6 & 10,550 & 6300 \\
\hline SE 11 & Medical college & 78.1193 & 8.7895 & 18 & 12 & 7.6 & 2350 & 1470 \\
\hline SE 12 & Brayant nagar & 78.1325 & 8.7869 & 16 & 13 & 7.7 & 1840 & 1840 \\
\hline SE 13 & C.G.E Colony & 78.1441 & 8.7872 & 22 & 17.5 & 7.7 & 10,470 & 6500 \\
\hline SE 14 & Fisher Colony & 78.1525 & 8.7975 & 15.3 & 9 & 7.9 & 1900 & 1170 \\
\hline SE 15 & Shunmugapuram & 78.1449 & 8.7987 & 16 & 8 & 7.4 & 2570 & 1570 \\
\hline SE 16 & Annanagar & 78.1298 & 8.8041 & 9.3 & 5 & 7.5 & 2490 & 1560 \\
\hline SE 17 & Third Mile & 78.1159 & 8.7885 & 16.3 & 10.2 & 7.8 & 910 & 580 \\
\hline SE 18 & Meelavitan & 78.1321 & 8.7937 & 19.8 & 15 & 7.1 & 8720 & 5300 \\
\hline SE 19 & Sipcot & 78.0855 & 8.8024 & 29.5 & 25 & 7.8 & 1830 & 1150 \\
\hline SE 20 & Sterlite & 78.0866 & 8.8192 & 70 & 30 & 8.8 & 4810 & 3100 \\
\hline SE 21 & Jothi nagar & 78.1118 & 8.8423 & 50 & 28 & 10.2 & 2000 & 1290 \\
\hline SE 22 & Melarasadi & 78.1161 & 8.8686 & 29 & 22 & 7.5 & 12,650 & 7600 \\
\hline SE 23 & Puthur Pandiapuram & 78.1203 & 8.8516 & 32.3 & 19 & 8 & 1440 & 910 \\
\hline SE 24 & Mapilaiurani & 78.1338 & 8.8357 & 16.9 & 9.5 & 8.1 & 350 & 2300 \\
\hline SE 25 & Devispuram & 78.1445 & 8.8361 & 46 & 18.5 & 7.5 & 6200 & 3800 \\
\hline SE 26 & Siluvaipatti & 78.1545 & 8.8395 & 18 & 15 & 7.4 & 19,100 & 10,200 \\
\hline SE 27 & Talamuthu nagar & 78.1544 & 8.8289 & 20.3 & 13 & 7.7 & 12,820 & 7600 \\
\hline SE 28 & Thresh puram & 78.1613 & 8.8163 & 16.3 & 7.3 & 7.8 & 2630 & 1580 \\
\hline SE 29 & State bank colony & 78.1419 & 8.8155 & 16.3 & 4.4 & 7.5 & 2780 & 1700 \\
\hline SE 30 & Mapilaiurani South & 78.1333 & 8.8311 & 9.6 & 5.5 & 7.5 & 7730 & 4800 \\
\hline SE 31 & Ayya samy street & 78.1251 & 8.8172 & 16.3 & 8 & 8 & 3160 & 1940 \\
\hline SE 32 & Palyapuram & 78.1156 & 8.8146 & 19.6 & 8.1 & 7.9 & 7500 & 4500 \\
\hline SE 33 & Pandarapatti & 78.1074 & 8.8237 & 49 & 27 & 7.9 & 2600 & 1570 \\
\hline SE 34 & Vijay company & 78.0964 & 8.832 & 76 & 15 & 7.9 & 7900 & 4800 \\
\hline SE 35 & Sankarperi entrance & 78.1012 & 8.8233 & 19.3 & 15 & 7.5 & 8070 & 4700 \\
\hline SE 36 & Kalangarai & 78.1019 & 8.7688 & 25.4 & 11.2 & 7.9 & 840 & 530 \\
\hline
\end{tabular}

Organization for Standardization, 2000). Groundwater samples were analysed for total coliform bacteria, faecal coliform bacteria, Escherichia coli and faecal streptococci. The MPN method was used to determine the presence of gas producing lactose fermenters and MPN of coliforms present in $100 \mathrm{~mL}$ of water. After $24 \mathrm{~h}$ of incubation at $37{ }^{\circ} \mathrm{C}$ in Lauryl Sulphate Tryptose Broth, tubes with turbidity and gas production were recorded as total coliform bacteria and a loopful of culture from the positive tubes was transferred into EC broth. Tubes with turbidity and gas production were recorded as faecal coliform bacteria after $24 \mathrm{~h}$ of incubation at $44.5+0.5^{\circ} \mathrm{C}$. From the positive tubes of EC broth, a loopful of culture was streaked on Eosine methylene blue agar (EMB), and colonies showing metallic sheen were recorded as presumptive E. coli. Further, typical colonies on EMB agar were purified and subjected to IMViC tests and confirmed as E. coli. Pour plate technique using Kenner Faecal agar was employed for the estimation of faecal streptococcal count, and typical colonies were counted after incubation at $37{ }^{\circ} \mathrm{C}$ for $48 \mathrm{~h}$ 
Table 2 Statistical measures such as minimum, maximum, average and standard deviation in pre-monsoon period

\begin{tabular}{|c|c|c|c|c|c|c|c|c|c|c|c|c|c|c|c|}
\hline $\begin{array}{l}\text { Water quality } \\
\text { parameters }\end{array}$ & $\mathrm{pH}$ & $\mathrm{EC}$ & TDS & $\mathrm{Na}$ & $\mathrm{K}$ & $\mathrm{Ca}$ & $\mathrm{Mg}$ & $\mathrm{HCO}_{3}$ & $\mathrm{CO}_{3}$ & $\mathrm{Cl}$ & $\mathrm{SO}_{4}$ & $\mathrm{PO}_{4}$ & $\mathrm{NO}_{3}$ & $\mathrm{~F}$ & $\mathrm{TH}$ \\
\hline \multicolumn{16}{|c|}{ Pre-monsoon period (PRM) } \\
\hline $\begin{array}{l}\text { Minimum } \\
\text { concentration }\end{array}$ & 7.1 & 350 & 530 & 27 & 5 & 11 & 15 & 0 & 0 & 36 & 19 & 0.1 & 0 & 0.16 & 138.18 \\
\hline $\begin{array}{l}\text { Maximum } \\
\text { concentration }\end{array}$ & 10.2 & 19100 & 10,200 & 1,400 & 400 & 570 & 442 & 756 & 168 & 5885 & 1272 & 0.1 & 14 & 4.8 & 2642.46 \\
\hline Average & 7.6 & 4887.7 & 3016.11 & 408.77 & 63.41 & 139.66 & 118.08 & 293.25 & 46 & 899.41 & 354.72 & 0.1 & 5.65 & 0.76 & 835.07 \\
\hline
\end{tabular}

Fig. 3 Spatial distribution map of the electrical conductivity

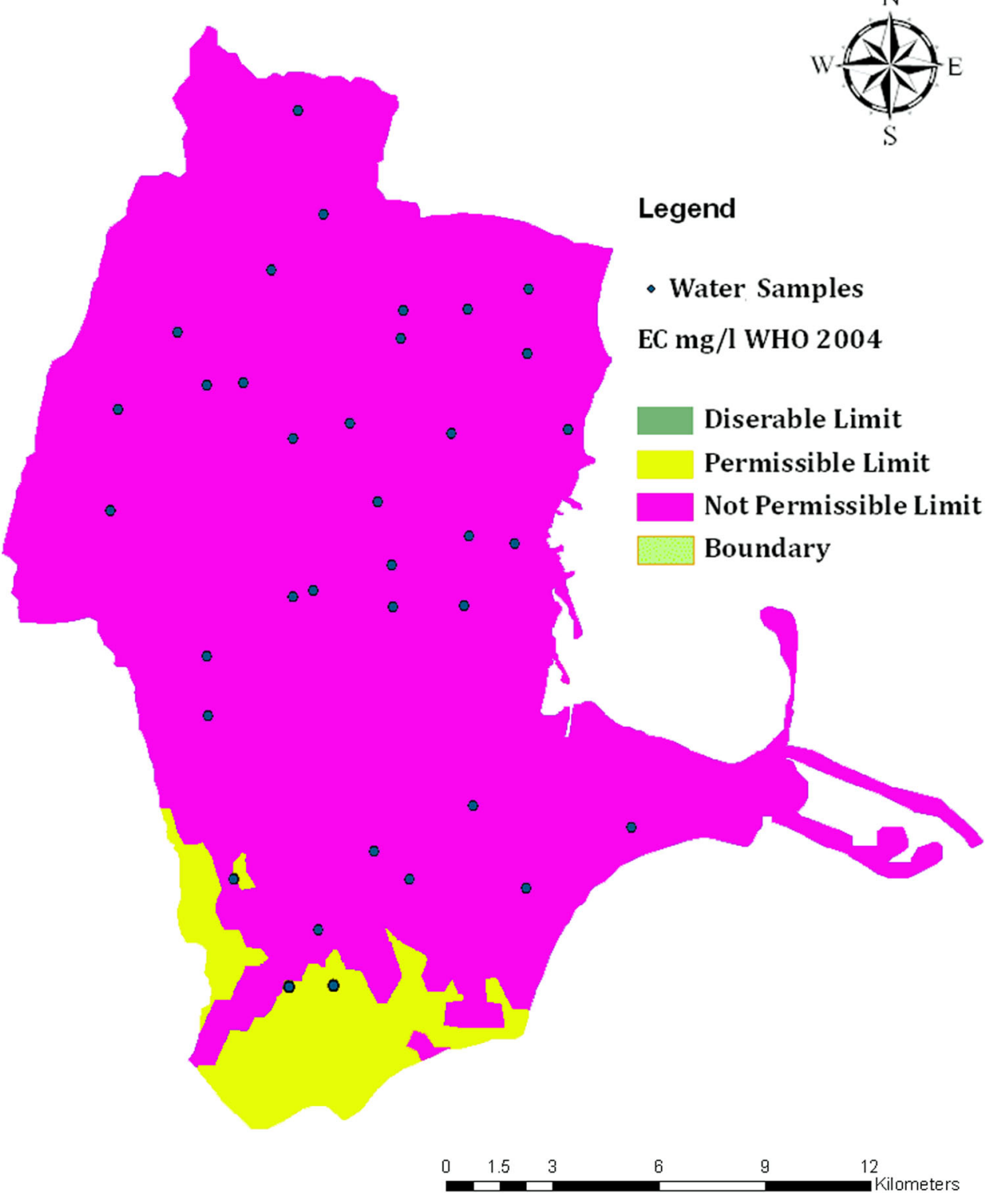


Fig. 4 Box plot of the major element in the in the study area

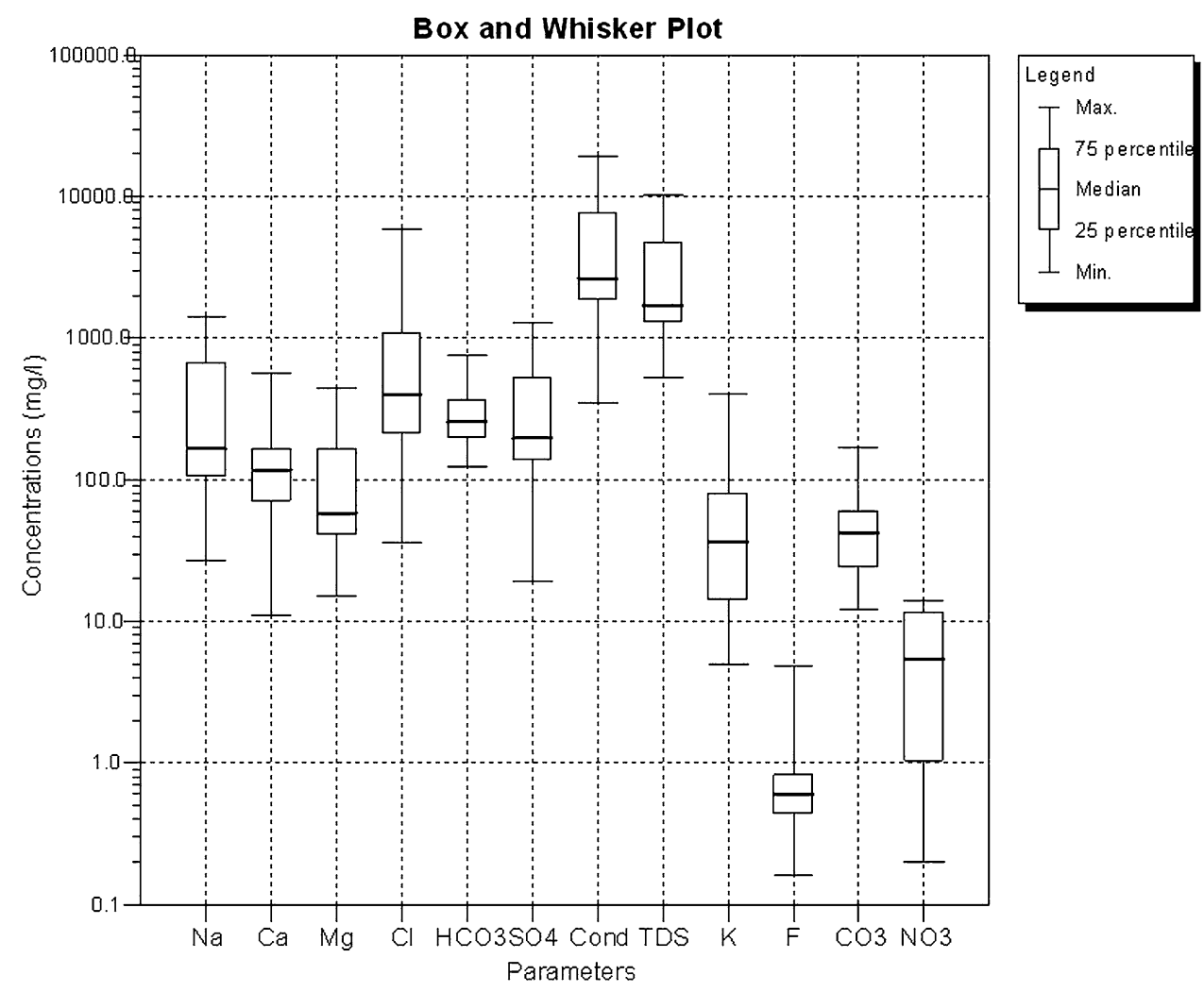

and expressed as colony forming unit (CFU) per $\mathrm{ml}$ or $\mathrm{g}$ of the sample. Salmonella was confirmed following standard procedures (AOAC 1998). Salmonella was detected by preenrichment in lactose broth, selective enrichment in tetrathionate broth and selenite cysteine broth, followed by selective plating on Xylose Lysine Deoxycholate agar and Bismuth sulphite agar. Typical colonies were purified them subjected to biochemical tests and finally confirmed serologically using poly ' $\mathrm{O}$ ' and poly ' $\mathrm{H}$ ' antisera (AOAC 1998).

\section{Concept of IDW}

The base map of Thoothukudi area was digitized from survey of India toposheet using ArcGIS 9.3 software. The precise locations of sampling points were determined in the field using GARMIN 12 Channel GPS, and the exact longitudes and latitudes of sampling points are imported in GIS platform (Selvam et al. 2014d, f). The spatial distribution for groundwater quality parameters like trace elements and bacterial elements was done with the help of spatial analyst modules in ArcGIS 9.3 software. Inverse distance weighted (IDW) interpolation technique was used for spatial modelling. IDW interpolation determines cell values using a linearly weighted combination of a set of sample points. The weight is a function of inverse distance. Further an input point is from the output cell location, the less importance it has in the calculation of the output value. The output value for a cell using IDW is limited to the range of the input values used to interpolate. Because the IDW is a weighted distance average, the average cannot be greater than the highest or lesser than the lowest input. Therefore, it cannot create ridges or valleys if these extremes have not already been sampled. Also, because of the averaging, the output surface will not pass through the sample points. The best results from IDW are obtained when sampling is sufficiently dense to represent the local variation that needs to be simulated. Thus, IDW technique is ideal for analysis in respect of water quality data from various sampling points densely spread out. If the sampling of input points is sparse or very uneven, the results may not adequately represent the desired surface.

\section{Results and discussion}

\section{Salient features of major ion chemistry}

Table 2 summarizes results of the various physical and chemical parameters including statistical measures such as minimum, maximum, average and standard deviation analysed groundwater samples from the study area. TDS values ranges from 530 to $10200 \mathrm{mg} / \mathrm{l}$, with an average value of $3016 \mathrm{mg} / \mathrm{l}$. The High concentration of TDS in the 
Table 3 Statistical measures such as minimum, maximum, average and standard deviation in pre-monsoon period

\begin{tabular}{|c|c|c|c|c|c|}
\hline \multicolumn{6}{|l|}{ Pre-monsoon } \\
\hline $\begin{array}{l}\text { Water quality } \\
\text { parameters }\end{array}$ & $\begin{array}{l}\text { Minimum } \\
\text { concentration }\end{array}$ & $\begin{array}{l}\text { Maximum } \\
\text { concentration }\end{array}$ & Average & $\mathrm{SD}$ & $\begin{array}{l}\text { Percentage of samples exceeding } \\
\text { allowable limits in WHO (2004) }\end{array}$ \\
\hline $\mathrm{Al}$ & 0.011 & 0.837 & 0.084594 & 0.136 & 12 \\
\hline $\mathrm{Si}$ & 0.026 & 23.45 & 2.235606 & 5.907 & $*$ \\
\hline $\mathrm{V}$ & 0.0021 & 0.052 & 0.01008 & 0.010 & $*$ \\
\hline $\mathrm{Cr}$ & 0.0015 & 0.08 & 0.013086 & 0.013 & 3 \\
\hline Mn & 0.00095 & 0.424 & 0.040315 & 0.078 & 0 \\
\hline $\mathrm{Fe}$ & 0.0018 & 0.357 & 0.123033 & 0.080 & 15 \\
\hline $\mathrm{Ni}$ & 0.000082 & 0.011 & 0.005192 & 0.003 & 0 \\
\hline Co & 0.000077 & 0.0273 & 0.002004 & 0.005 & $*$ \\
\hline $\mathrm{Cu}$ & 0.0027 & 0.2365 & 0.031661 & 0.060 & 0 \\
\hline $\mathrm{Zn}$ & 0.00094 & 0.87 & 0.203493 & 0.197 & 0 \\
\hline As & 0.00087 & 0.0837 & 0.015796 & 0.025 & 42 \\
\hline $\mathrm{Se}$ & 0.00027 & 0.1497 & 0.086987 & 0.050 & 82 \\
\hline $\mathrm{Rb}$ & 0.00028 & 0.8501 & 0.107435 & 0.249 & $*$ \\
\hline $\mathrm{Sr}$ & 0.00043 & 2.00036 & 0.504263 & 0.447 & $*$ \\
\hline Mo & 0.000025 & 0.0086 & 0.002297 & 0.002 & 0 \\
\hline $\mathrm{Ag}$ & 0.000022 & 0.0024 & 0.000272 & 0.000 & $*$ \\
\hline $\mathrm{Cd}$ & 0.000012 & 0.0021 & 0.000296 & 0.000 & 0 \\
\hline $\mathrm{Sb}$ & 0.000015 & 0.007 & 0.000889 & 0.002 & 6 \\
\hline $\mathrm{Ba}$ & 0.00053 & 0.057 & 0.012131 & 0.012 & 0 \\
\hline $\mathrm{Pb}$ & 0.00045 & 0.018 & 0.004375 & 0.003 & 9 \\
\hline
\end{tabular}

* WHO not given any guideline value

groundwater sample is due to leaching of salts from soil and also by anthropogenic activities. The EC value is measured in micro-semens per centimetre and is a measure of salt content of water in the form of ions. The EC values range from $350-19,100 \mu \mathrm{s} / \mathrm{cm}$ with an average value $4887 \mu \mathrm{s} / \mathrm{cm}$. The spatial distribution of EC in groundwater of the study area is shown in Fig. 3. The Not Permissible (NP) limit of EC (3125 mg/l) was observed towards N-NE, $\mathrm{N}-\mathrm{NW}$ and central directions. Highly soluble rocks contribute more ions and impart high conductivity. To determine the suitability of groundwater of any purposes, it is essential to classify the groundwater depending upon their hydrochemical properties based on their EC values (Selvam et al. 2014b, c). The negative logarithm of hydrogen ion concentration $(\mathrm{pH})$ ranges from 7.1 to 10.2 with an average value 7.7. The $\mathrm{pH}$ value as low as 7.1 was recorded in Meelavitan and the highest was found in Jothi nagar near Sankarapari with a value of 10.2. This shows that the groundwater of the study area is dominantly alkaline in nature. The slight alkalinity may be due to the presence of bicarbonate ions, which are produced by the free combination of $\mathrm{CO}_{2}$ with water to form carbonic acid, which affects the $\mathrm{pH}$ of the water (Azeez et al. 2000). Amongst the cations, the concentrations of $\mathrm{Na}, \mathrm{Ca}, \mathrm{Mg}$ and $\mathrm{K}$ ions range from 27 to 1400,11 to 570,15 to 442 and 5 to
$400 \mathrm{mg} / \mathrm{l}$, with a mean of $409.00,139.60,118.00$ and $63.00 \mathrm{mg} / \mathrm{l}$ during PRM seasons. The order of abundance of chemical concentration is $\mathrm{Na}^{+}>\mathrm{K}^{+}>\mathrm{Mg}^{2+}>\mathrm{Ca}^{2+}$, respectively, during the PRM seasons. For the anions, the concentrations of $\mathrm{HCO}_{3}, \mathrm{Cl}, \mathrm{SO}_{4}, \mathrm{NO}_{3}, \mathrm{~F}$ and $\mathrm{PO}_{4}$ range from 0 to 756,36 to 5885,19 to 1272,0 to $14,0.16$ to 4.8 and 0 to $0.1 \mathrm{mg} / 1$ with a mean of $293.25,899.41,354.72$, $5.65,0.76$ and $0.1 \mathrm{mg} / \mathrm{l}$, respectively. The order of abundance of chemical concentration is $\mathrm{Cl}^{-}>\mathrm{SO}_{4}{ }^{2-}>-$ $\mathrm{F}>\mathrm{NO}_{3}>\mathrm{PO}_{4}$ during the period (Fig. 4).

\section{Heavy metal distribution}

For the protection of human health, guidelines for the presence of heavy metals in water have been set by different International Organisations such as United States Environmental Protection Agency, World Health Organization (WHO) and the European Union Commission (Marcovecchio et al. 2007). Thus, heavy metals have permissible limits in water as specified by these organizations. The summary of the heavy metal results of laboratory analyses conducted on the samples are in Table 1 .

The concentration of lead in groundwater varies from 0.000 to $0.018 \mathrm{mg} / \mathrm{l}$ with an average concentration of $0.004 \mathrm{mg} / \mathrm{l}$ (Table 3 ), which is beyond the desirable limit 
Fig. 5 Spatial distribution map of the Arsenic ion

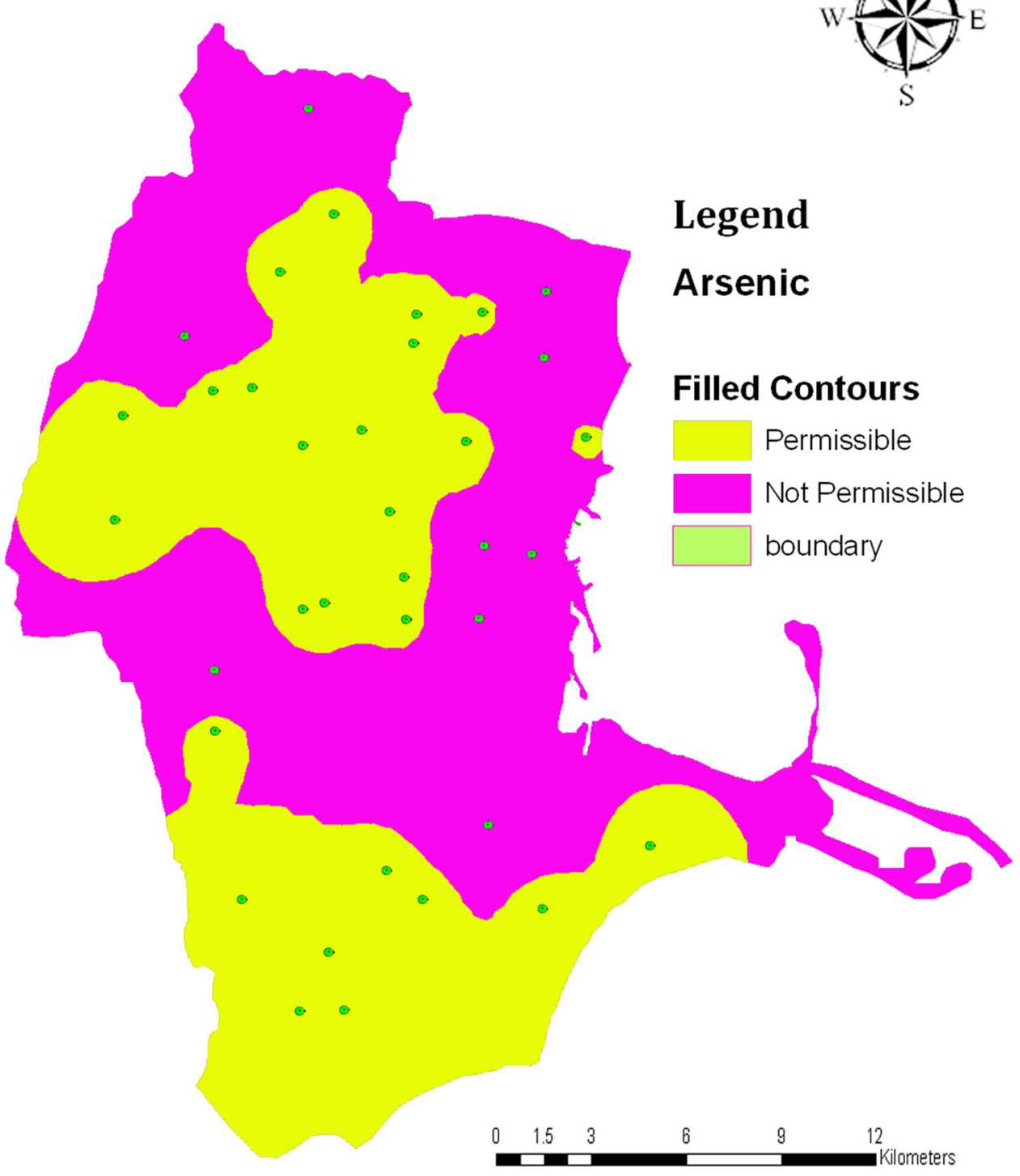

of $0.01 \mathrm{mg} / \mathrm{l}$ as recommended by WHO (2004). The lead concentration in groundwater of the study area is within the maximum allowable limit in all the sample locations. The main sources of lead contamination are industrial discharges from smelters, battery manufacturing units, run off from contaminated land areas, atmospheric fall out and sewage effluents.

Arsenic concentration in the groundwater varies from 0.000 to $0.083 \mathrm{mg} / \mathrm{l}$ with an average concentration of $0.015 \mathrm{mg} / \mathrm{l}$. The maximum allowable limit of arsenic ion concentration in groundwater is $0.01 \mathrm{mg} / \mathrm{l}$ as per WHO 2004 classification. According to WHO standards, $42 \%$ of the samples have exceeded the permissible limits and $58 \%$ of the samples are within the permissible limit (Table 3). Not Permissible limit of arsenic was observed towards
North West, North East and central portion (Fig. 5). A higher concentration of Arsenic in the study area is due to industrial waste leaching or percolating through the subsurface. The study area STERLITE is one of the copper industries located near Thoothukudi town which produces copper from copper concentrates. Arsenic trioxide is obtained as a byproduct from dusts and residues that are produced during the treatment of other metal ores such as gold and copper (Puthiyasekar et al. 2010). The high arsenic concentration is due to the anthropogenic activities like poultry waste, brick making and agricultural practices (Selvam et al. 2014a).

Chromium concentration in the groundwater varies from 0.001 to $0.080 \mathrm{mg} / \mathrm{l}$ with an average concentration of $0.013 \mathrm{mg} / \mathrm{l}$. As per WHO 2004 standard only one sample 
Fig. 6 Spatial distribution map of the Iron ion

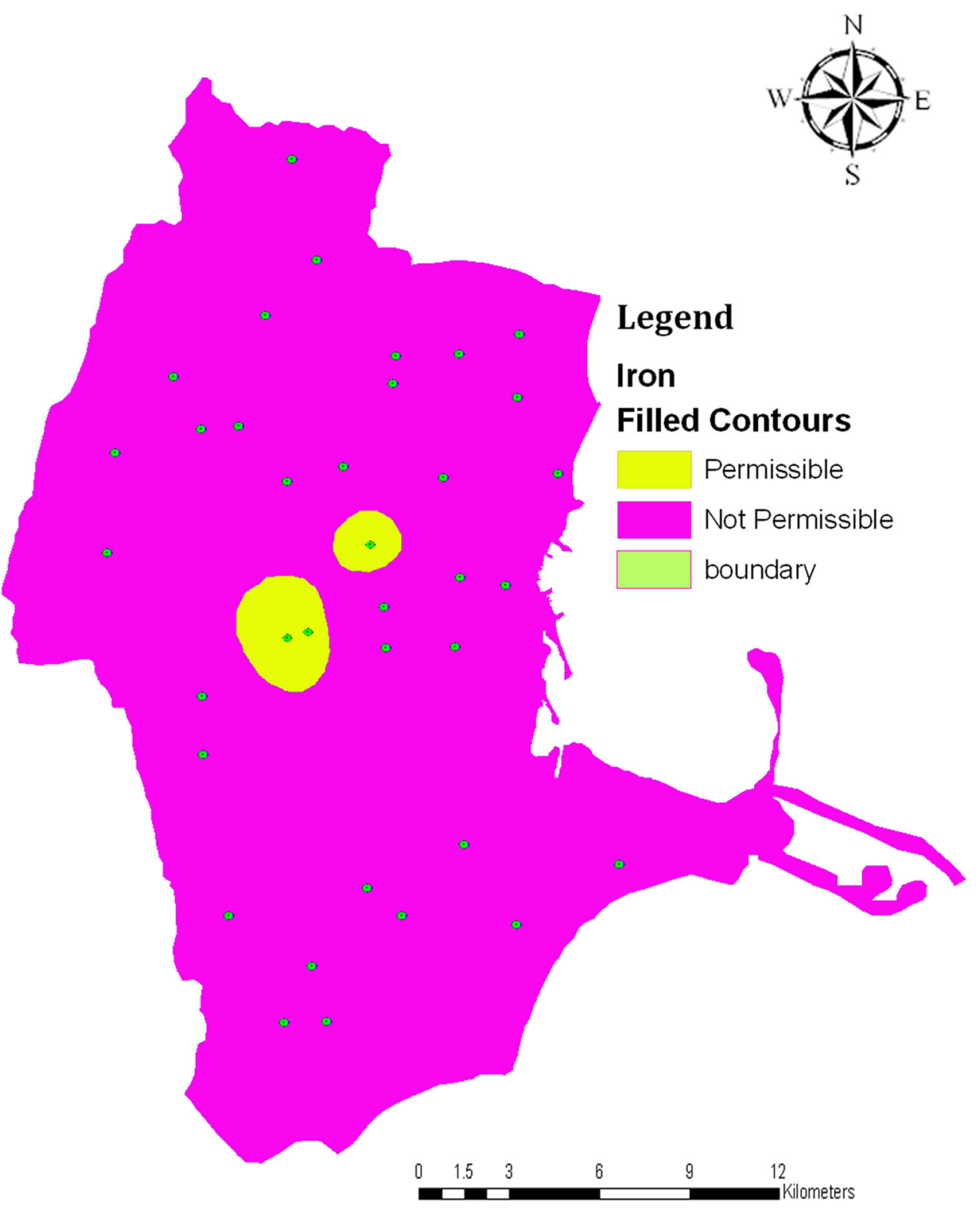

exceeds the permissible limit, which may be due to industrial activity. The most common man-made sources of chromium in groundwater are burning of fossil fuels, mining effluent, effluent from metallurgical, chemical and other industrial operations (Leung and Jiao 2006). The risk to human health is through ingestion only-drinking, cooking and teeth brushing. Well water with chromium levels greater than $0.05 \mathrm{mg} / \mathrm{l}$ may safely be used for bathing, hand washing and dishwashing (Selvam et al. 2015)

The concentration of iron in the groundwater varies from 0.001 to $0.357 \mathrm{mg} / \mathrm{l}$, with an average of $0.123 \mathrm{mg} / \mathrm{l}$. The maximum allowable limit of iron ion concentration in groundwater is $0.3 \mathrm{mg} / \mathrm{l}$ as per WHO 2004 classification. It is found that $85 \%$ of the samples are within the desirable limit and $15 \%$ of the samples have crossed the permissible limit in the area, according to the WHO standard 2004 (Fig. 6). The NP limit of $0.3 \mathrm{mg} / \mathrm{l}$ was observed in small patches of central portion due to anthropogenic activity. Iron can be found in meat, whole meal products, potatoes and vegetables. The human body absorbs iron in animal products faster than iron in plant products. Iron is an essential part of haemoglobin, the red colouring agent of the blood that transports oxygen through our bodies. Higher Fe concentrations in the aquifers might have been the results of interaction from oxidized $\mathrm{Fe}$ minerals and organic matters and subsequent dissolution of $\mathrm{Fe}_{2} \mathrm{CO}_{3}$ at a comparatively lower $\mathrm{pH}$ (Mondal et al. 2010). This type of water was clear when drawn from the well, but shortly changes into cloudy and then turns brown due to 
Fig. 7 Spatial distribution map of the Aluminium ion

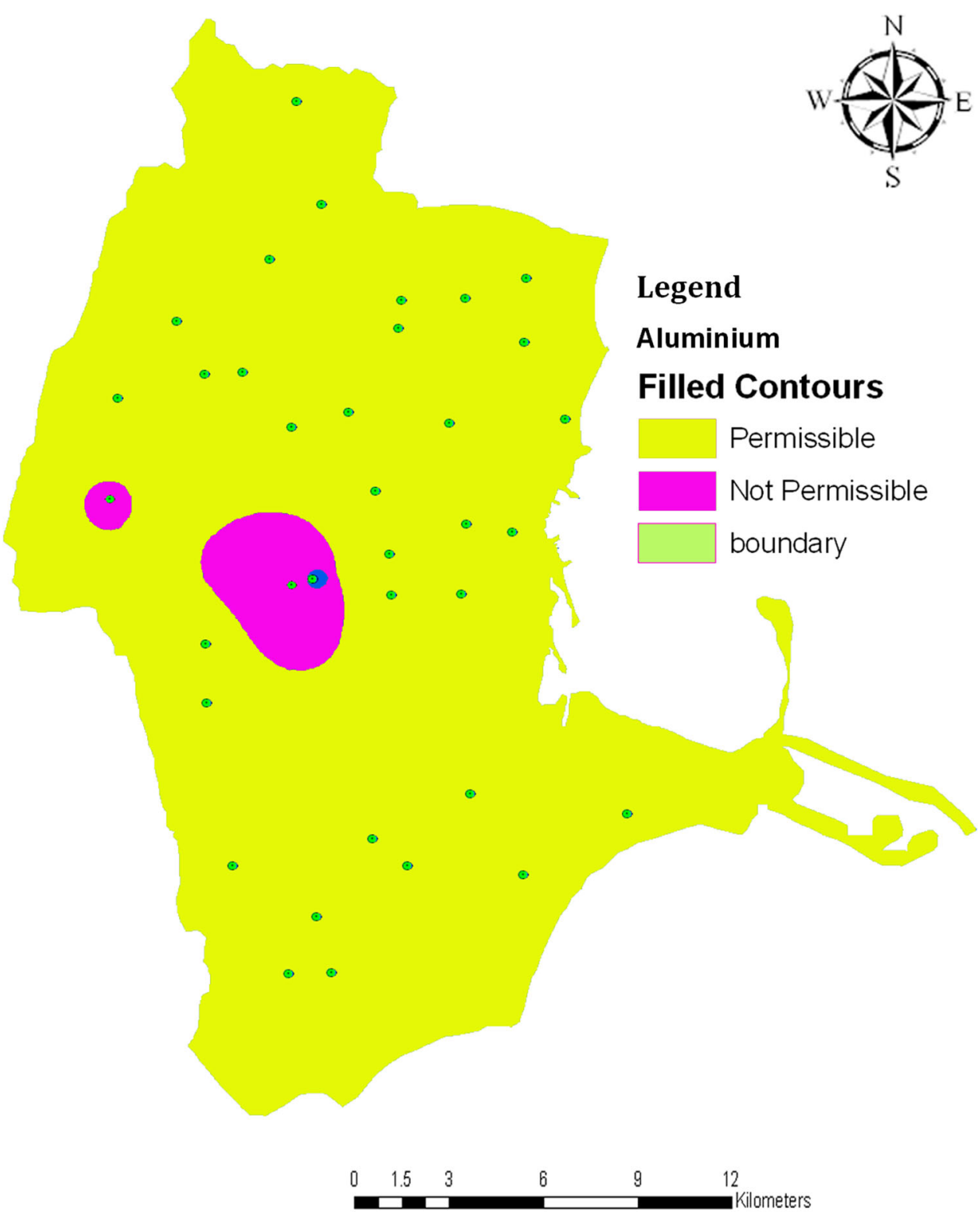

precipitation of $\mathrm{Fe}(\mathrm{OH})_{3}$. Another reason for high $\mathrm{Fe}$ concentration may be due to the removal of dissolved oxygen by organic matter, leading to reduced conditions. Under reducing conditions, the solubility of Fe-bearing minerals (siderite, marcasite, etc.) increase in water, leading to the enrichment of dissolved iron in groundwater (Applin and Zhao 1989; White et al. 1991).

The concentration of Aluminium in groundwater ranges from 0.011 to $0.837 \mathrm{mg} / \mathrm{l}$ with an average concentration of $0.084 \mathrm{mg} / \mathrm{l}$. The maximum allowable limit of aluminium ion concentration in groundwater is $0.2 \mathrm{mg} / \mathrm{l}$ as per WHO 2004 classification. $88 \%$ of samples fall within the maximum allowable limit, while $12 \%$ of samples exceed the permissible limits (Fig. 7). This figure clearly shows that a not permissible limit of Aluminium $(0.2 \mathrm{mg} / \mathrm{l})$ was observed in the central portion and small patches of western portion of study area. The source of Aluminium in the study area groundwater samples may be through the weathering of bedrock and soil or it may be related sources like industries, which introduced Aluminium into groundwater. Aluminium occurs naturally in some rocks and drainage from mines. Aluminium formed during mineral weathering of feldspars, such as orthoclase, anorthite, albite, micas and bauxite, subsequently ends up in clay minerals.

The concentration of selenium in the groundwater varies from 0.000 to $0.149 \mathrm{mg} / \mathrm{l}$ with an average concentration of $0.086 \mathrm{mg} / \mathrm{l}$. The maximum allowable limit of selenium ion concentration in groundwater is $0.01 \mathrm{mg} / \mathrm{l}$ as per WHO 2004 classification. According to WHO standards, $82 \%$ of 
Fig. 8 Spatial distribution map of the Selenium ion

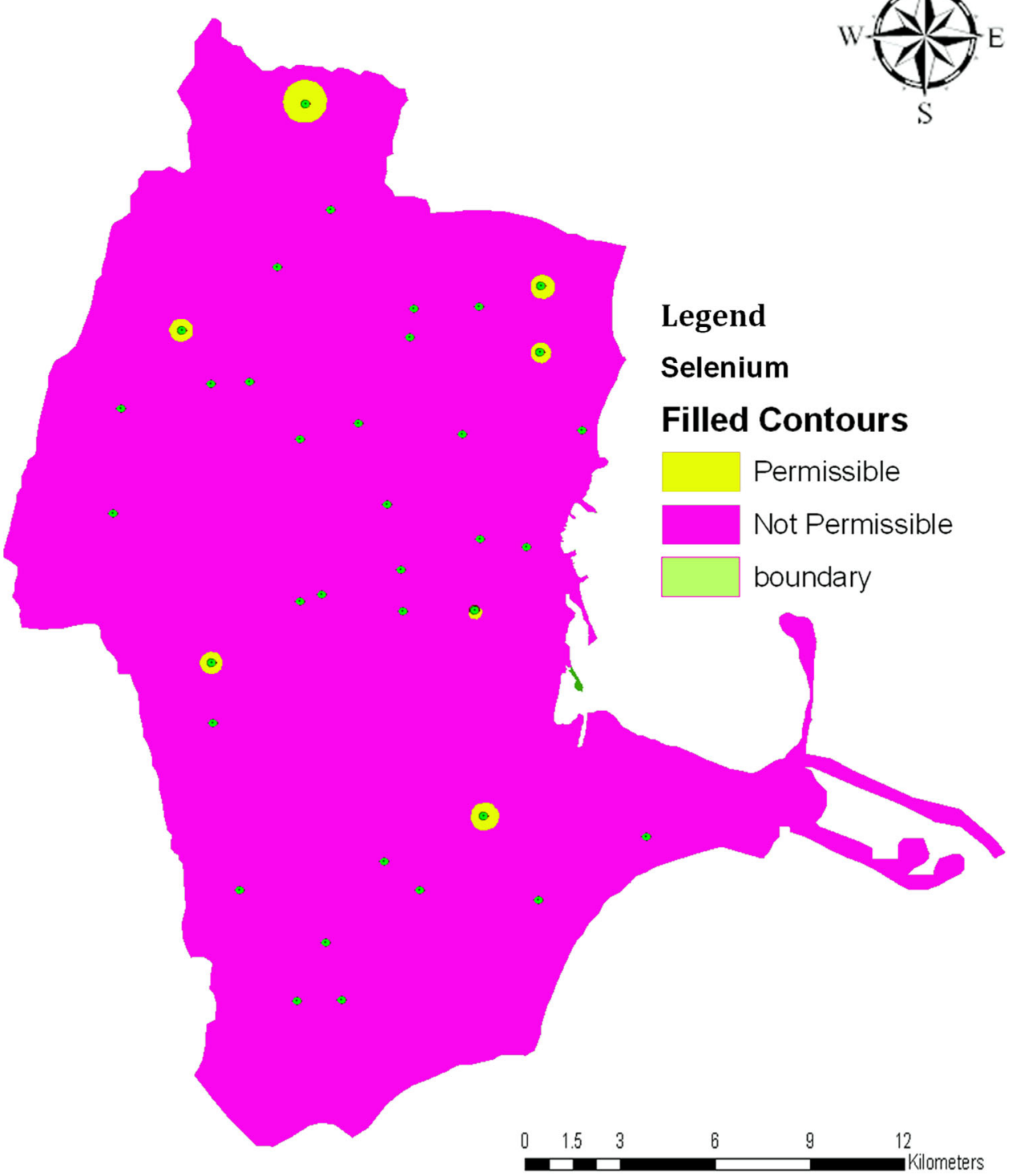

the samples exceed the permissible limits and only $18 \%$ (Table 3) of the samples are within the permissible limit (Fig. 8). NP limit of selenium was observed in N-NE, NNW, S-SE, S-SW direction and central portion. Selenium is a natural heavy metal associated with specific geological formations and in groundwater it occurs as a mixture of selenite and selenate. Diminutive amount of selenium was beneficial, but excess amount was toxic in groundwater. The potential health effects were on hair, finger nail loss and numbness in fingers or toes (Negrel et al. 2004).

The concentration of antimony in the groundwater varies from 0.000 to $0.007 \mathrm{mg} / \mathrm{l}$ with an average concentration of $0.001 \mathrm{mg} / \mathrm{l}$. The maximum allowable limit of selenium ion concentration in groundwater is $0.005 \mathrm{mg} / \mathrm{l}$ as per WHO 2004 classification. Especially, people who work with antimony suffer the effects of exposure by breathing in antimony dusts. Human exposure to antimony may take place not only by breathing air, drinking water and by eating foods that contain it but also by skin contact with soil, water and other substances that contain it (Sang et al. 2008).

Cadmium concentration in the groundwater varies from 0.000 to $0.002 \mathrm{mg} / \mathrm{l}$ with an average concentration of $0.000 \mathrm{mg} / \mathrm{l}$. The range of nickel concentration in groundwater varies from 0.000 to $0.011 \mathrm{mg} / \mathrm{l}$, with an average concentration of $0.005 \mathrm{mg} / \mathrm{l}$. The range of molybdenum concentration in groundwater varies from 0.000 to $0.008 \mathrm{mg} / \mathrm{l}$, with an average concentration of $0.002 \mathrm{mg} / \mathrm{l}$. The concentration of barium in the groundwater ranges from 0.000 to $0.057 \mathrm{mg} / \mathrm{l}$ with an average concentration of 
Table 4 Results of faecal indicator bacteria in the study area

\begin{tabular}{|c|c|c|c|c|c|}
\hline Place & $\begin{array}{l}\text { Total coliform bacteria } \\
\left(\mathrm{MPN} \mathrm{ml} \mathrm{m}^{-1}\right)\end{array}$ & $\begin{array}{l}\text { Faecal coliform bacteria } \\
\left(\mathrm{MPN} \mathrm{ml} \mathrm{m}^{-1}\right)\end{array}$ & $\begin{array}{l}\text { Escherichia coli } \\
\left(\mathrm{MPN} \mathrm{ml}^{-1}\right)\end{array}$ & $\begin{array}{l}\text { Faecal streptococci } \\
\left.(\mathrm{CFU} \mathrm{ml})^{-1}\right)\end{array}$ & Salmonella \\
\hline Athimarapatti & Nil & Nil & Nil & Nil & Absent \\
\hline Muthyapuram & 2.3 & 12 & 06 & Est. $<10$ & Absent \\
\hline Thirespuram & 142 & 143 & 39 & $9.20 \times 10^{2}$ & Present \\
\hline Tsunami Nagar & 1.6 & 45 & 03 & Est. $<10$ & Absent \\
\hline $\begin{array}{l}\text { Fishing old } \\
\text { Harbour }\end{array}$ & 48 & 44 & 40 & $2.00 \times 10^{1}$ & Present \\
\hline Medical College & 0.6 & Nil & 2.0 & Nil & Absent \\
\hline Iniko Nagar & 145 & 141 & 23 & $5.00 \times 10^{2}$ & Absent \\
\hline Meela arasadi & Nil & Nil & Nil & Est. $<10$ & Absent \\
\hline Beach & 1.9 & 2.2 & 0.9 & $1.00 \times 10^{1}$ & Absent \\
\hline Sterlite & 2.3 & Nil & 12 & Est. $<10$ & Absent \\
\hline $\begin{array}{l}\text { Mappillaiurani } \\
\text { beach }\end{array}$ & 140 & 141 & 29 & $7.40 \times 10^{2}$ & Absent \\
\hline
\end{tabular}

$0.012 \mathrm{mg} / \mathrm{l}$. The concentration of rubidium in the groundwater varies from 0.000 to $0.850 \mathrm{mg} / \mathrm{l}$, with an average concentration of $0.107 \mathrm{mg} / \mathrm{l}$. In the study area, copper concentration varies from 0.002 to $0.236 \mathrm{mg} / \mathrm{l}$ with an average concentration of $0.031 \mathrm{mg} / \mathrm{l}$. Zinc concentration in groundwater of the study area varies from 0.000 to $0.870 \mathrm{mg} / \mathrm{l}$ with an average concentration of $0.20 \mathrm{mg} / \mathrm{l}$. Manganese concentration in the groundwater ranges from 0.000 to $0.424 \mathrm{mg} / \mathrm{l}$ with an average value of $0.040 \mathrm{mg} / \mathrm{l}$. The concentrations of cadmium, nickel, molybdenum, barium, rubidium, copper and zinc in groundwater are within the maximum allowable limit as per WHO standard.

Cobalt concentration in the groundwater ranges from 0.000 to $0.027 \mathrm{mg} / \mathrm{l}$ with an average value of $0.002 \mathrm{mg} / \mathrm{l}$, while Vanadium concentration in the groundwater varies from 0.002 to $0.052 \mathrm{mg} / \mathrm{l}$ with an average concentration of $0.010 \mathrm{mg} / \mathrm{l}$. The range of silver concentration in groundwater varies from 0.000 to $0.002 \mathrm{mg} / \mathrm{l}$, with an average concentration of $0.000 \mathrm{mg} / \mathrm{l}$. The concentration of strontium in the groundwater varies from 0.000 to $2.000 \mathrm{mg} / \mathrm{l}$, with an average concentration of $0.504 \mathrm{mg} / \mathrm{l}$. BIS and WHO have not given any guideline value for Cobalt, Vanadium, Silver and Strontium concentration in the groundwater. The strontium concentration was higher in the study area indicating that the source could be anthropogenic through agricultural activities an input of strontium to some extent it depends on the content of fertilisers and carbonate additives and manure like cattle, poultry, etc. (Negrel et al. 2004). Strontium concentrations in soil may also be attributed to dumping waste and industrial wastes. Strontium in soil dissolves in water, so that it would be able to leach deeper into the ground and enter the groundwater.

\section{Microbiological analysis}

In microbiological analysis, MPN test was conducted in 11 water samples in order to find out faecal coliforms (total coliform bacteria, faecal coliform bacteria, E. coli and faecal streptococci) through biochemical tests (Table 4; Fig. 9). Further, the samples were screened for Salmonella to study the reliability of faecal indicator bacteria as an index of human pathogenic bacteria.

The test indicated that the presence of Faecal coliform bacteria were detected at the maximum detectable limits and were detected in water samples near costal area (Coastal Beaches), which was found to be the more polluted sampling site. Samples of water from Mappillaiurani Beach, Iniko Nagar, Thirespuram present higher values indicating the contamination of ground water from fishing activity, making the water unfit for drinking purposes (Fig. 10). Total coliform bacteria were high in water samples of all coastal fishing centres and were at the maximum detectable level of over MPN $145 \mathrm{ml}^{-1}$ and were detected at eastern part (Iniko Nagar) of the study. This may be due to the settlements nearby which lead to defecation along the beaches. Similar trend in total coliform bacteria was observed in Thirespuram, Mappillaiurani Beach, though the maximum level of MPN $>140 \mathrm{ml}^{-1}$ was recorded in the study period (Fig. 10). This might be due to the mixing of sewage from Thoothukudi town through the Buckle channel. E. coli and Faecal streptococci showed greater variation among samples during season and the highest values were recorded in water samples from Fishing old Harbour, Mappillaiurani Beach and Thirespuram. It may be due to the fishing activity 
Fig. 9 Sampling site of the Microbiological study

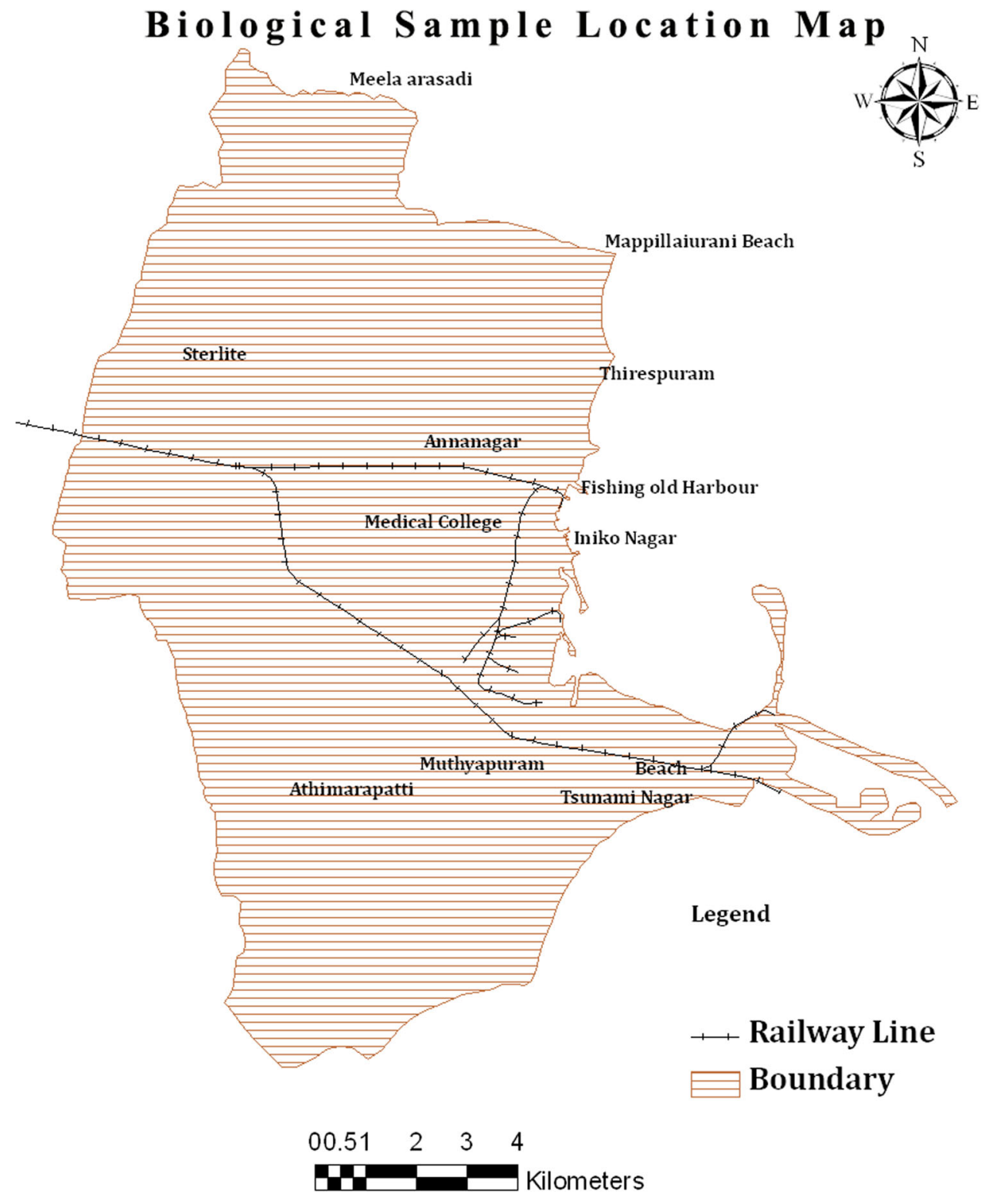

which is one of the main reasons for contamination by E. coli and Faecal streptococci in the study area (Fig. 10). Although faecal streptococci gives only supplementary evidence of faecal pollution, they are still considered better indicators than coliforms because of their inability to grow and multiply in water or virgin soils (Vaidya et al. 2001). Faecal indicator bacteria such as total coliforms, faecal coliforms and E. coli that are excreted by humans and warm-blooded animals pass sewage treatment plants in large amounts, and survive, preserving their pathogenicity for a certain time. Salmonella might be isolated in samples of the Thoothukudi study area, even when the concentration of faecal coliform bacteria was low. On the contrary, Geldreich (1972) could establish a relationship and reported that when the faecal coliform was over MPN $20 \mathrm{ml}^{-1}$,
Salmonella was always present in water samples from canal communities along Texas coast (Goyal et al. 1977). However, in this study Salmonella was absent in many samples even when the faecal coliform bacteria were over MPN $145 \mathrm{ml}^{-1}$.

\section{Management implications}

A number of issues emerge which need to be incorporated into future strategies for groundwater management. Definitions of baseline are given here which can form the basis for distinguishing pristine from polluted waters as well as criteria for identifying modern waters with only traces of human impact from more polluted waters. In common, physico-chemical treatments offer various advantages such 
Fig. 10 Spatial distribution map of the faecal indicator bacteria

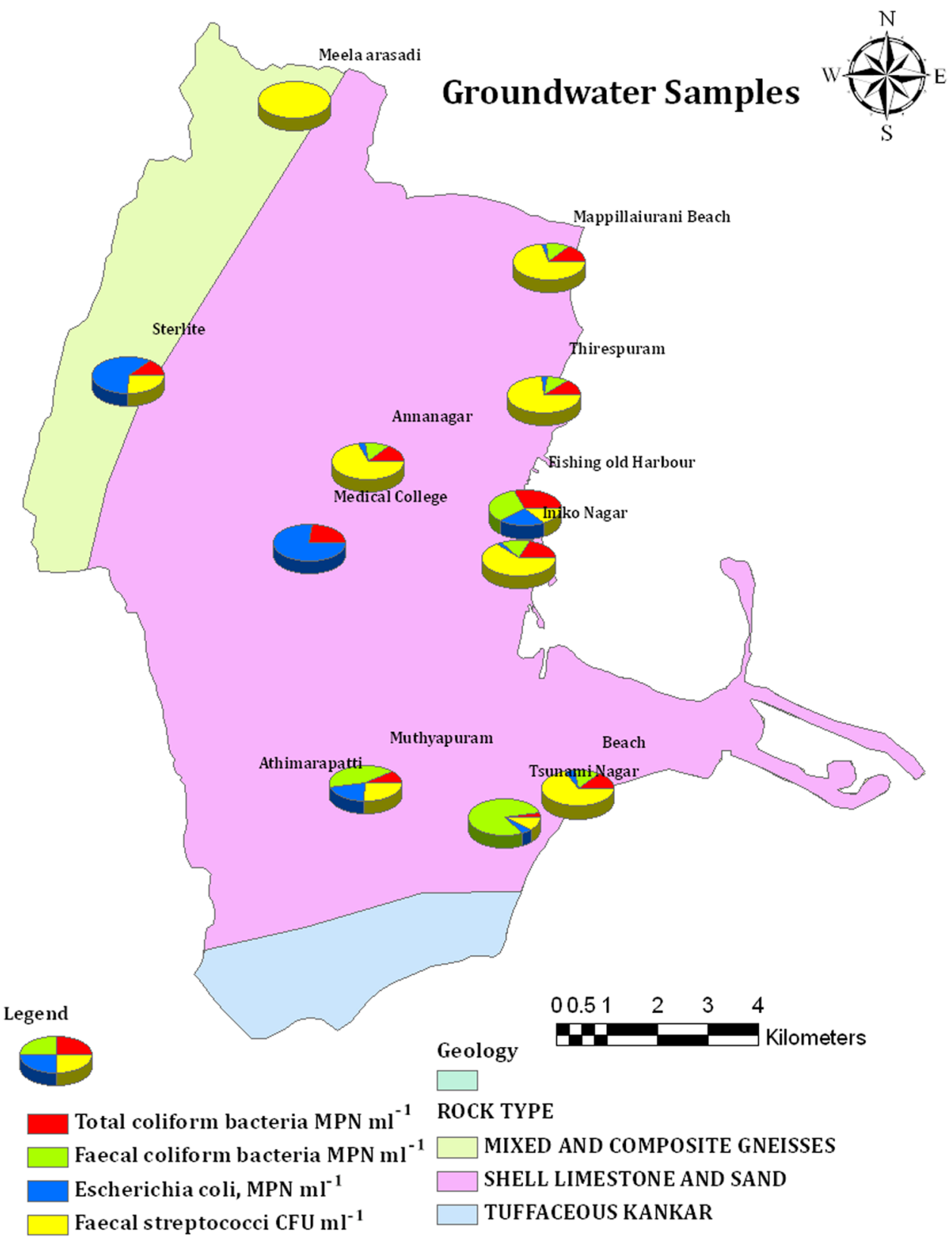

as their rapid process, ease of operation and control, and flexibility to change of temperature. Unlike in biological system, physico-chemical treatment can accommodate variable input loads and flow such as seasonal flows and complex discharge. Whenever it is required, chemical plants can be modified. In addition, the treatment system requires a lower space and installation cost. Their benefits, however, are outweighed by a number of drawbacks such as their high operational costs due to the chemicals used, high-energy consumption and handling costs for sludge disposal. However, with reduced chemical costs and a feasible sludge disposal, physico-chemical treatments have been found as one of the most suitable treatments for inorganic effluent (Kurniawan et al. 2006). In wastewater systems containing heavy metals with other organic pollutants, the presence of one species usually impedes the removal of the other. For instance, hydrometallurgy, a classical process to recover metals, is inhibited by the presence of organic compounds and a pre-treatment step, to remove or destroy organics, is generally required; pyrometallurgy which is able to decontaminate systems from organic pollutants and recover metals suffers from lack of controllability, demanding extremely high temperatures. The most promising methods to treat such complex systems are the photocatalytic ones which consume cheap photons from the UV-near visible region. These photo 
catalysts serve as electron relays, from the organic substrates to metal ions. Thus, they induce both degradation of organic pollutants and recovery of metals in one-pot systems, operable at traces of the target compounds (less than $\mathrm{ppm})$. Regulations are in place to regulate the release of toxic metals in the environment to ensure safety and health of the workers as well as the public in general. The following remedial suggestion can reduce the risk of trace metals and biological contamination in the present study area:

- Monitoring of water and soil in the vicinity of the toxic metal processing units needs to be carried out more rigorously for the specific metal.

- Recycling/reprocessing of wastes containing toxic metals and biological contamination needs to be given greater emphasis not only from environmental and health considerations but also as a resource conservation measure.

- Guidelines for proper management of tailings and slags containing toxic metals should be prepared taking into consideration techno-economic feasibility.

- Tailings dumps and process wastes lying in locations close to the processing units need to be remediated on priority.

- Health monitoring of workers engaged in the processing of toxic metals/compounds should be carried out regularly.

\section{Conclusion}

This study shows that the Thoothukudi Corporation of Tamil Nadu has been affected by trace elements and microbiological contamination in groundwater. The study reveals that Arsenic, Selenium, Lead, Bismuth, Aluminium, Iron and Vanadium are, in general, concentrated above the permissible limit (WHO 2004) in groundwater of the area of investigation. The increasing concentration of these elements in the groundwater of the study area is mainly originating from industrial effluents of copper industries, alkali chemical industry, fertiliser industry, thermal power plant, sea food industries, shipping activities and also from municipal waste water. Faecal pollution was found that fishing old harbour, mappillaiurani beach and thirespuram are highly affected from total coliform bacteria, faecal coliform bacteria and E. coli. This might be due to the mixing of sewage from Thoothukudi town through the Buckle channel and fishing activity.

In view of these findings, there is a need to monitor more closely the environment under review and put in place appropriate checks and balances to preserve the health of communities within the vicinity of the industrial areas, as the effects of heavy metals are bio-accumulative and pose great dangers to the health of humans, animals and plants. From the results of the present study, we can suggest that the Government should adopt some treatment technologies in the following study areas to minimize these heavy metals in groundwater and surface water for providing safe drinking water to the public.

Acknowledgments The author S.Selvam is thankful to Department of Science and Technology, Government of India, New Delhi for awarding INSPIRE Fellowship to carry out this study (Ref. No. DST/ INSPIRE FELLOWSHIP/2010/(308), Date: 3rd August 2010). Thanks are also due to Head, Geochemical Division, National Geophysical Research Institute, Hyderabad, India for providing facility to carry out the trace element analysis of the water samples in ICPMS lab at NGRI. This study was also supported by the Fisheries College and Research Institute, Tamil Nadu Veterinary and Animal Sciences University, Thoothukudi-628 008, India.

Open Access This article is distributed under the terms of the Creative Commons Attribution 4.0 International License (http:// creativecommons.org/licenses/by/4.0/), which permits unrestricted use, distribution, and reproduction in any medium, provided you give appropriate credit to the original author(s) and the source, provide a link to the Creative Commons license, and indicate if changes were made.

\section{References}

Antony Ravindran A, Selvam S (2014) Coastal disaster damage and neotectonic subsidence study using 2D ERI technique in Dhanushkodi, Rameshwaram Island, Tamil Nadu India. Middle-East J Sci Res 19(8):1117-1122

AOAC (1998) Official methods of analysis, 8th edn. Association of Official Analytical Chemists, Washington, DC

Applin KR, Zhao N (1989) The kinetics of Fe(II) oxidation and well screen encrustation. Ground Water 27:168-174

Azeez PA, Nadarajan NR, Mittal DD (2000) The impact of monsoonal wetland on groundwater chemistry. Pollut Res 19(2):249-255

Balasubramanaian A, Thirugnana RS, Chellaswamy R, Radhakrishnan V (1993) Numerical modeling for prediction and control of saltwater encroachment in the coastal aquifers of Tuticorin, Tamil Nadu. Tech Report, 21

Carter DE, Fernando Q (1979) Chemical toxicology. J Chem Educ 56(8):491-493

Dutka BJ, Bell JB (1973) Isolation of salmonella from moderately polluted waters. J Water Pollut Control Fed 45:316-319

Fatoki OS, Okoro HK, Adekola FA, Ximba BJ, Synman RG (2012) Bioaccumulation of metals in black mussels (Mytilus galloprovincialis) in Cape Town Harbour, South Africa. Environmentalist 32:48-57

Geldreich EE (1972) Buffalo lake recreational water quality: a study in bacteriological data interpretation. Water Res 6:913-924

Goyal SM, Gerba CP, Melnick JL (1977) Occurrence and distribution of bacterial indicators and pathogens in canal communities along the Texas coast. Appl Environ Microbiol 34:139-149

Handa B (1981) Hydro geochemistry water quality and water pollution in U. P. Technical Report, CGWB, Ministry of Irrigation, p 317

International Organization for Standardization (2000) Water quality-detection and enumeration of Escherichia coli and coliform 
bacteria. Part 1 membrane filtration method (ISO 9308-1:2000). International Organization for Standardization, Geneva

Kurniawan TA, Chan GYS, Lo WH, Babel S (2006) Physicochemical treatment techniques for wastewater laden with heavy metals. Chem Eng J 118:83-98

Lerner DN, Harris B (2009) The relationship between land use and groundwater resources and quality. Land Use Policy 26:5265-5273

Leung CM, Jiao JJ (2006) Heavy metal and trace element distributions in groundwater in natural slopes and highly urbanized spaces in min-levels area, Hong Kong. Water Res 40:753-767

Macler AB, Merkel CJ (2000) Current knowledge on groundwater microbial pathogens and their control. Hydrogeol J 8:29-40

Mandal A, Sengupta D (2006) An assessment of soil contamination due to heavy metals around a coal-fired thermal power plant in India. Environ Geol 51(3):409-420

Marcovecchio JE, Botte SE, Freije RH (2007) Heavy metals, major metals, trace elements. In: Nollet LM (ed) Handbook of water analysis, 2nd edn. CRC Press, London, pp 275-311

Mondal NC, Singh VS, Puranik SC, Singh VP (2010) Trace element concentration in groundwater of Pesarlanka Island, Krishna Delta India. Environ Monit Assess 163:215-227

Negrel P, Petelet-Graud E, Widory D (2004) Strontium isotope geochemistry of alluvial groundwater: a tracer for groundwater resources characterization. Hydrol Earth Syst Sci 8(5):959-972

Nouri J, Mahvi AH, Babaei A, Ahmadpour E (2006) Regional pattern distribution of groundwater fluoride in the Shush aquifer of Khuzestan County Iran. Fluoride 39(4):321-325

Puthiyasekar C, Neelakandan MA, Poongothai S (2010) Heavy metal contamination in bore water due to industrial pollution and polluted and non polluted sea water intrusion in Thoothukudi and Tirunelveli of South Tamil Nadu, India. Bull Environ Contam Toxicol 85:598-601

Ramesh R, ShivKumar K, Eswaramoorthi S, Purvaja GR (1995) Migration and contamination of major and trace elements in groundwater of Madras City, India. Environ Geol 25:126-136

Sang Y, Fasheng L, Qingbao G, Cunzhen L, Jiaqing C (2008) Heavy metal-Contaminated groundwater treatment by a novel nanofiber membrane. Desalination 223:349-360

Selvam S (2012) Use of remote sensing and GIS techniques for land use and land cover mapping of Tuticorin Coast Tamil Nadu. Univ J Environ Res Technol 2(4):233-241

Selvam S (2014) Irrigational Feasibility of Groundwater and Evaluation of Hydrochemistry Facies in the SIPCOT Industrial Area, South Tamil Nadu, India: A GIS Approach. Water Qual Expo Health. doi:10.1007/s12403-014-0146-2

Selvam S (2015) A preliminary investigation of lithogenic and anthropogenic influence over fluoride ion chemistry in the groundwater of the southern coastal city, Tamil Nadu India. Environ Monit Assess 187:106. doi:10.1007/s10661-015-4326-8

Selvam S, Sivasubramanian P (2012) Groundwater potential zone identification using geoelectrical survey: a case study from Medak district, Andhra Pradesh India. Int J Geomat Geosci 3(1):55-62
Selvam S, Manimaran G, Sivasubramanian P (2013a) Hydrochemical characteristics and GIS-based assessment of groundwater quality in the coastal aquifers of Tuticorin Corporation, Tamil Nadu India. Appl water Sci 3(1):145-159

Selvam S, Manimaran G, Sivasubramanian P (2013b) Cumulative Effects of Septic System Disposal and Evolution of Nitrate Contamination Impact on Coastal Groundwater in Tuticorin, South Tamil Nadu, India. Res J Pharm Biol Chem Sci 4(4):1207-1218

Selvam S, Manimaran G, Sivasubramanian P, Balasubramanian N, Seshunarayana T (2014a) GIS-based evaluation of water quality index of groundwater resources around Tuticorin coastal city, South India. Environ Earth Sci 71:2847-2867

Selvam S, Antony Ravindaran A, Rajamanickam M, Sridharan M (2014b) Microbial contamination in the sediments and groundwater of Tuticorin Corporation, South India using GIS. Int $\mathbf{J}$ Pharm Pharm Sci 6(4):337-340

Selvam S, Manimaran G, Sivasubramanian P, Seshunarayana T (2014c) Geoenvironmental resource assessment using remote sensing and GIS: a case study from southern coastal region. Res J Recent Sci 3(1):108-115

Selvam S, Magesh NS, Sivasubramanian P, Prince Soundranayagam J, Manimaran G, Seshunarayana T (2014d) Deciphering of groundwater potential zones in Tuticorin, Tamil Nadu, using remote sensing and GIS techniques. J Geol soc India 84:597-608

Selvam S, Magesh NS, Chidambaram S, Rajamanickam M, Sashikkumar MC (2014e) A GIS based identification of groundwater recharge potential zones using RS and IF technique: a case study in Ottapidaram taluk, Tuticorin district, Tamil Nadu. Environ Earth Sci. doi:10.1007/s12665-014-3664-0

Selvam S, Venkatramanan S, Singaraja C (2015) A GIS-based assessment of water quality pollution indices for heavy metal contamination in Tuticorin Corporation, Tamilnadu, India. Arab J Geosci. doi:10.1007/s12517-015-1968-3

Singaraja C, Chidambaram S, Srinivasamoorthy K, Anandhan P, Selvam S (2015) A Study on assessment of credible sources of heavy metal pollution vulnerability in groundwater of Thoothukudi Districts. Water Qual Expo Health, Tamil Nadu. doi:10. 1007/s12403-015-0162-x

Vaidya SY, Vala AK, Dube HC (2001) Bacterial indicators of faecal pollution at Bhavnagar coast. Indian J Microbiol 41:37-39

Van Ryneveld MB, Fourie AB (1997) A strategy for evaluating the environmental impact of on-site sanitation systems. Water SA 23(4):279-291

Vanloon GW, Duffy SJ (2005) The Hydrosphere. Environmental chemistry: a global perspective, 2nd edn. Oxford University Press, New York, pp 197-211

White AF, Benson SM, Yee AW, Woolenberg HA, Flexser S (1991) Groundwater contamination at the Kesterson reservoir, California- Geochemical parameters influencing selenium mobility. Water Resour Res 27:1085-1098

WHO (2004) Guidelines for drinking water quality, vol 1. World Health Organization, Geneva 